\title{
Exaggerated Placental Site
}

National Cancer Institute

\section{Source}

National Cancer Institute. Exaggerated Placental Site. NCI Thesaurus. Code C7105.

A non-neoplastic trophoblastic disorder characterized by the presence of an increased

number of implantation-site intermediate trophoblasts infiltrating the endometrium and myometrium extensively. It is associated with pregnancy or abortion. 